\title{
Endostatin Modulates VEGF-Mediated Barrier Dysfunction in the Retinal Microvascular Endothelium
}

\author{
Brenda B. Brankin \\ Technological University Dublin, brenda.brankin@tudublin.ie \\ M. Campbell \\ University College Dublin \\ P. Canning \\ Queens University, Belfast.
}

See next page for additional authors

Follow this and additional works at: https://arrow.tudublin.ie/scschbioart

Part of the Life Sciences Commons, and the Medicine and Health Sciences Commons

\section{Recommended Citation \\ Brankin, B.Campbell, M.,Canning, P., Gardiner,T. Stitt, A.:Endostatin Modulates VEGF-Mediated Barrier Dsfunction in the Retinal Microvascular Endothelium. doi:10.1016/j.exer.2005.01.005}

This Article is brought to you for free and open access by the School of Biological Sciences at ARROW@TU Dublin. It has been accepted for inclusion in Articles by an authorized administrator of ARROW@TU Dublin. For more information, please contact arrow.admin@tudublin.ie, aisling.coyne@tudublin.ie,gerard.connolly@tudublin.ie. Funder: Fighting Blindness Ireland

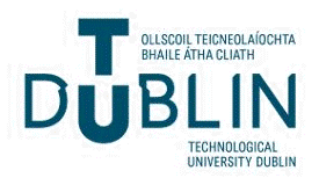




\section{Authors}

Brenda B. Brankin, M. Campbell, P. Canning, T. Gardiner, and A. Stitt 


\section{Article Outline}

\section{Introduction}

Tissues of the central nervous system, including the brain and retina, depend on intact blood-brain and blood-retinal barriers (BRB), respectively, to partition them from the systemic circulation (reviewed in Takata et al., 1997). The BRB consists of the innerBRB (iBRB) and the outerBRB (oBRB) with the endothelial membranes of the retinal vessels forming the $\mathrm{iBRB}$ while the retinal pigment epithelial cells and Bruchs membrane are the main structures involved in forming the oBRB. Breakdown of the inner blood retinal barrier (iBRB) is a major cause of visual loss in a number of human ocular disorders including diabetic retinopathy, sickle-cell disease and cystoid macular edema (Vinores et al., 1999, Vinores et al., 1995, Dorchy, 1993, Carney et al., 1986 and Barber, A.J). The endothelial cells of the iBRB are joined by highly specialised tight junctional complexes that, in part, confer highly selective properties to these vessels (Takata et al., 1997). Tight junctions make a seal around the circumference of cells and function as barriers preventing free diffusion of solutes through the paracellular pathway. Occludin and ZO-1 are key tight junction proteins. At the tight junction ZO-1 binds to the actin cytoskeleton through its carboxyl terminal end, and forms a bridge between the C-terminal sequences of occludin and $\beta$ actin.

The configuration of several tight junction proteins, including occludin and zonula occludens (ZO-1, -2 and -3), can be altered by selective phosphorylation of key components to modulate barrier integrity (Gonzalez-Mariscal et al., 2003). Increased expression of occludin has been found to correlate with improved barrier function (reviewed in Harhaj and Antonetti, 2004) and modulation of occludin phosphorylation regulates its cellular localisation (Wong, 1997).

Phosphorylation of ZO-1 may affect barrier properties, for instance ZO-1 tyrosine phosphorylation has been correlated with formation of tight junctions in glomeruli (Kurihara et al., 1995) and ZO-1 may also be regulated by serine and/or threonine phosphorylation (Balda et al., 1996).

The vasoactive growth factor vascular endothelial growth factor (VEGF) has been shown to affect tight junction integrity at the plasma membrane with rapid phosphorylation of the tight junction proteins occludin and ZO-1 and this has important consequences for iBRB function. VEGF induced changes in tight junction phosphorylation may serve as a mechanism by which VEGF has the capacity to regulate endothelial permeability (Antonetti et al., 1999). VEGF increases the permeability of the microvasculature. The permeability increase is associated with altered tight junction organisation (Barber and Antonetti, 2003). The signal transduction pathway and molecular targets responsible for the VEGF mediated increases in permeability are still being elucidated, whilst it has been shown that phosphorylation of occludin is linked with increases in permeability (Antonetti et al., 1999). VEGF activates phosphatidylinositol 3-kinase which may lead to activation of atypical PKC isoforms (Toker and Cantley, 1997). 
Endostatin is a $20 \mathrm{kDa}$ fragment of collagen XVIII, derived by selective proteolytic degradation of vascular basement membranes (Halfter et al., 1998). This peptide can prevent tumour angiogenesis (O'Reilly et al., 1997) and has also been shown to be efficacious in the eye by preventing retinal and choroidal neovascularisation (Mori et al., 2001, Auricchio et al., 2002 and Le Gat et al., 2003). Endostatin may also prevent vasopermeability responses by growth factors and recent studies have suggested that endostatin can reduce VEGF-induced retinal vascular permeability in double transgenic mice with inducible expression of $\mathrm{VEGF}_{165}$ in the retina (Takahashi et al., 2003). VEGF-induced permeability was assessed via $\left[{ }^{3} \mathrm{H}\right]$ mannitol permeation, fluorescein angiography and assessment of edema was conducted by measurement of retinal thickness. These recent studies reported mice, when given sub-retinal injections of a bovine immunodeficiency viral vector expressing endostatin, showed a marked decrease in retinal vascular permeability, neovascularisation and retinal detachment (Takahashi et al., 2003). However, exact concentrations of endostatin required to decrease the VEGF induced permeability and effects on tight junction expression were not elucidated.

In the current study, we hypothesise that $\mathrm{VEGF}_{165}$-induced leakage from the retinal microvascular endothelium may be modulated by controlled concentrations of endostatin. We present evidence herein that endostatin affects VEGF-mediated permeability across monolayers of RMEC's in vitro via regulation of tight junction integrity, and significantly decreases VEGF-mediated retinal vaso-permeability in vivo.

\section{Methods}

\subsection{Cell Culture}

Primary retinal microvascular endothelial cells (RMECs) were isolated from bovine retinas as described previously (Stitt et al., 2000) and used at between passage numbers $3-5$. The cells were propagated in growth medium (DMEM) containing $10 \%$ porcine serum until they formed confluent monolayers. Six hours prior to growth factor treatment, RMECs were stepped down from 10 to $2 \%$ porcine serum. Recombinant human VEGF $_{165}$ (Sigma Aldrich, Ireland) was added to give a final concentration of 10 or $100 \mathrm{ng} \mathrm{ml}^{-1}$. Recombinant human endostatin (Calbiochem, Darmstadt, Germany) was added to give final concentrations of 10, 20, $100 \mathrm{ng} \mathrm{ml}^{-1}$, $1 \mu \mathrm{g} \mathrm{ml}^{-1}$ or $10 \mu \mathrm{g} \mathrm{ml}^{-1}$. Cells were incubated with $\mathrm{VEGF}_{165}$ and/or Endostatin for $24 \mathrm{hr}$, after which time the monolayers were washed twice with ice-cold phosphatebuffered saline, and harvested in respective lysis buffers as described.

\subsection{FD-70 and FD-4 Permeability Assay}

RMEC's were seeded at a cell density of $5 \times 10^{5}$ cells $\mathrm{ml}^{-1}$ and grown to confluence on $0.1 \%$ gelatin coated Costar ${ }^{\circledR}$ Transwell $^{\circledR}$-Clear inserts (Corning Incorporated, New York, USA) with a pore size of $0.4 \mu \mathrm{M}$. Chambers were examined microscopically for integrity and uniformity of RMEC monolayers, medium was changed and VEGF $_{165}$ or endostatin added at the appropriate concentrations in triplicate inserts for each time point. Upon reaching confluence, $250 \mu \mathrm{g} \mathrm{ml}^{-1}$ FD-70 or FD-4 (Sigma Aldrich, Ireland) (in $400 \mu$ l growth medium), was added to the apical chambers of triplicate control (untreated) monolayers or, those previously exposed to $10 \mathrm{ng} \mathrm{ml}^{-1}$ 
$\mathrm{VEGF}_{165}, 20 \mathrm{ng} \mathrm{ml}^{-1}$ endostatin, or a combination of $10 \mathrm{ng} \mathrm{ml}^{-1} \mathrm{VEGF}_{165}$ and $20 \mathrm{ng} \mathrm{ml}^{-1}$ endostatin for $24 \mathrm{hr}$. RMEC's were placed on a shaker @ $37^{\circ} \mathrm{C}$, and at time 'zero', $150 \mu$ l growth medium was removed from each basolateral chamber, and replaced with new medium, bringing the basolateral volume to $1.8 \mathrm{ml}$. Sampling aliquots were taken every $15 \mathrm{~min}$ for $120 \mathrm{~min}$. The fluorescence of FD-70/FD-4 was determined in a fluorescence spectrofluorometer at an excitation wavelength of $490 \mathrm{~nm}$ and an emission wavelength of $515 \mathrm{~nm}$. The apparent permeability coefficient $\left(P_{\text {app }}\right)$ of FD-70/FD-4 was calculated using the following equation:

$\underline{P}_{\text {app }}(\mathrm{cm} / \mathrm{s})=\mathrm{d} Q / \mathrm{d} t \times 1 / A \times C_{0}$

Where $\mathrm{d} Q / \mathrm{d} t(\mu \mathrm{g} / \mathrm{s})$ is the rate of appearance of FD-70/FD-4 on the receiver side from 30 to 120 min after application of FD-70/FD-4. $\mathrm{C}_{\mathrm{o}}\left(\mu \mathrm{g} \mathrm{ml}^{-1}\right)$ is the initial FD-70/FD-4 concentration on the donor side, and $\mathrm{A}\left(\mathrm{cm}^{2}\right)$ is the effective surface area of the insert.

\subsection{Western Blot analysis}

\subsubsection{Occludin extraction}

An occludin-enriched extract was prepared according to the method of Dye et al. (2001). The cell monolayer was scraped, and homogenised with a 21-gauge needle, in boiling buffer containing $62.5 \mathrm{~mm}$ Tris, 2\% SDS, 10 Dithiothreitol, $10 \mu$ protease inhibitor cocktail/100 ml (Sigma Aldrich, Ireland). The homogenate was centrifuged at $10000 \mathrm{~g}$ for $20 \mathrm{~min} @ 4^{\circ} \mathrm{C}$, and the supernatant was removed for occludin analysis.

\subsubsection{ZO-1 extraction}

Confluent monolayers of RMECs were scraped and homogenised with a 21-gauge needle in buffer containing $200 \mathrm{~mm}$ HEPES, $1 \mathrm{~mm}$ EDTA, $300 \mathrm{~mm}$ KCL, $100 \mathrm{~mm}$ $\mathrm{MgCl}_{2}, 10$ (1 protease inhibitor cocktail/100 $\mathrm{ml}$. The homogenate was sonicated with four $5 \mathrm{sec}$ pulses at a frequency of 5.0, and the resulting cell lysate was centrifuged at $500 \mathrm{~g}$ for $15 \mathrm{~min} @ 4^{\circ} \mathrm{C}$. The supernatant was removed and centrifuged at $40000 \mathrm{~g}$ for $2 \mathrm{hr} @ 4^{\circ} \mathrm{C}$. The resulting supernatant was removed, and the plasma membrane enriched pellet was re-suspended in buffer containing $6 \mathrm{M}$ Urea, $0.1 \%$ Triton X-100, $10 \mathrm{~mm}$ Tris, $1 \mathrm{~mm}$ Dithiothreitol, $5 \mathrm{~mm}$ EGTA, $150 \mathrm{~mm} \mathrm{NaCl}, 10$ (1 protease inhibitor cocktail/100 ml (pH 8.0).

Protein concentrations were determined using the Micro-BCA ${ }^{\circledR}$ (Pierce, MSC, Dublin, Ireland) assay and a BSA standard curve, and equal amounts of protein were loaded onto SDS-PAGE gels. 10\% SDS-PAGE was used for occludin analyses, whilst $6 \%$ SDS-PAGE was used for ZO-1 analyses. Protein samples were separated by electrophoresis, and transferred to nitrocellulose membrane for $2 \mathrm{hr}$ using a semi-dry electroblot apparatus. Efficiency of protein transfer was determined using Ponceau-S solution (Sigma Aldrich, Ireland). Non-specific binding sites were blocked by incubating the membrane at room temperature with 5\% non-fat dry skimmed milk in TBS (0.05 M Tris, $150 \mathrm{~mm} \mathrm{NaCl,} \mathrm{pH} \mathrm{7.5)} \mathrm{for} 2 \mathrm{hr}$. Membranes were briefly washed with TBS, and incubated with polyclonal rabbit anti-occludin (Zymed, San Francisco, CA) (1:1000) or polyclonal rabbit anti-ZO-1 (Santa-Cruz Biotech, CA) (1:1000). Antibodies were incubated with membranes overnight at $4^{\circ} \mathrm{C}$. The membranes were washed with TBS, and incubated with a secondary anti-rabbit ( $\mathrm{IgG}$ ) antibody with a 
HRP conjugate (1:2500), for $3 \mathrm{hr}$ at room temperature. Immune complexes were detected using enhanced chemiluminescence (ECL). After exposure, the X-Ray film was scanned and densitometric analysis was performed using UVP-Gel Works ${ }^{\circledR}$.

\subsection{Immunoprecipitation analysis}

$5 \mu \mathrm{g}$ of rabbit anti-occludin antibody was added to $400 \mu \mathrm{g}$ of plasma-membrane enriched fraction of RMEC in Immunoprecipitation (IP) buffer (20 mm Tris, $\mathrm{pH} 7.5$, $150 \mathrm{~mm} \mathrm{NaCl}, 1 \mathrm{~mm}$ EDTA, $1 \mathrm{~mm}$ EGTA, $1 \%$ Triton X-100, $1 \mathrm{~mm} \mathrm{Na} \mathrm{VO}_{4}$, protease inhibitor cocktail), and incubated overnight at $4{ }^{\circ} \mathrm{C}$ on a roller for mixing. $20 \mu \mathrm{g}$ Protein-A agarose beads (Sigma Aldrich, Ireland) were added and incubated for $30 \mathrm{~min}$. with agitation at $4^{\circ} \mathrm{C}$. Following four washes with $500 \mu \mathrm{l}$ IP buffer, the mixture was centrifuged at $14000 \mathrm{~g}$ for $2 \mathrm{~min}$ at $4^{\circ} \mathrm{C}$ and supernatant removed. The pellet was resuspended in $50 \mu \mathrm{l}$ of $0.1 \mathrm{M}$ Glycine $\mathrm{pH} 2.5$, vortexed and incubated with agitation for $10 \mathrm{~min}$ at $4^{\circ} \mathrm{C}$. The mixture was centrifuged at $14000 \mathrm{~g}, 4^{\circ} \mathrm{C}$, for $2 \mathrm{~min}$, and supernatant removed. $5 \mu \mathrm{l}$ of $1 \mathrm{M}$ Tris $\mathrm{pH} 8.0$ was added to each tube to neutralise the $\mathrm{pH} .15 \mu \mathrm{l}$ of $5 \mathrm{X}$ concentrated electrophoresis sample buffer (125 mm Tris $\mathrm{pH} 6.8$, $4 \%$ SDS, $10 \%$ glycerol, $0.006 \%$ bromophenol blue, $2 \% \beta$-mercaptoethanol) was added to each sample, and boiled for $5 \mathrm{~min}$. The supernatant was loaded onto a $7.5 \%$ SDS-PAGE gel, electrophoresed, transferred was added to nitrocellulose membrane and probed with rabbit anti-phosphoserine polyclonal antibody, rabbit antiphosphothreoine antibody or rabbit anti-phosphotyrosine antibody (Chemicon, Temecula, CA), followed by secondary antibody labelled with HRP.

\subsubsection{Alakaline-Phosphatase pre-treatment}

Lysates of Control (Un-treated), and RMEC's treated for $24 \mathrm{hr}$ with $100 \mathrm{ng} \mathrm{ml}^{-1}$ Endostatin were incubated for $45 \mathrm{~min}$ with $50 \mathrm{U} \mathrm{ml}^{-1}$ Alkaline Phosphatase (Sigma Aldrich, Ireland) at $30^{\circ} \mathrm{C}$. (Maik-Rachline et al. (2004)). Lysates were subsequently immunoprecipitated with rabbit anti-occludin antibody. Following immunoprecipitation, samples were loaded onto a 7.5\% SDS-PAGE gel, electrophoresed, and transferred to nitrocellulose membrane and probed with rabbit anti-phosphoserine polyclonal antibody.

\subsection{Evan's blue assay for quantitation of inner blood retinal barrier breakdown in vivo}

All studies adhered to the ARVO statement for the use of Animals in Ophthalmic and Vision Research. C57/B16 mice were anaesthetised with gaseous isofluorane, and the right eye of each of the mice was injected through the sclera, in the region of the ciliary body, using a $26 \mathrm{~g}$ sterile needle (Venisystems Ltd, Abbot Ireland Ltd, Sligo, Eire).

Animals with a mean weight of $21.24 \mathrm{~g}$ were injected as follows: Control Injection with no growth factor $(n=10), 30 \mathrm{ng}$ VEGF $(n=10), 60 \mathrm{ng}$ Endostatin $(n=10), 30 \mathrm{ng}$ VEGF+60 ng Endostatin ( $n=8)$. The final volume of each injection was $3 \mu 1$.

After $24 \mathrm{hr}$, animals were again anaesthetised with isofluorane, and Evan's blue was injected intravenously ( $45 \mathrm{mg} \mathrm{kg}^{-1}$ ). Upon administration of Evan's blue, mice were 
seen to visibly turn blue, and this was used as a confirmation that the dye had been taken into the bloodstream.

After $3 \mathrm{hr}$, animals were perfused using citrate buffer at a pressure of $120 \mathrm{mmHg}$ for $2 \mathrm{~min}$. and both eyes were removed immediately. Eyes were bisected at the equator, and retinas were removed under an operating microscope. After determination of the retinal wet weight, the retinas were completely dried by placing in a Speed Vac overnight at $60^{\circ} \mathrm{C}$. Retinal dry weights were subsequently determined, and retinas then crushed in $120 \mu \mathrm{l} \mathrm{Formamide} \mathrm{at} 70^{\circ} \mathrm{C}$ for $18 \mathrm{hr}$, in order to remove Evan's blue. After this time, the extract was centrifuged with a filter centrifuge tube @ $15000 \mathrm{rpm}$ for $30 \mathrm{~min}$. in order to remove retinal debris. The filtrate was subsequently read on the spectrophotometer at an absorbance of $620 \mathrm{~nm}$, the absorbance maximum for Evan's Blue, and $740 \mathrm{~nm}$, the absorbance minimum. The concentration of dye in the extracts was calculated from a standard curve of Evan's blue in formamide. Blood-retinal barrier breakdown was calculated as previously outlined by Xu et al. (2001).

\subsection{Statistical analysis}

Statistical analysis of all results obtained was performed using Students $t$-test, with results representative of mean and standard deviation and significance represented by a $P$-value of $\leq 0.05$. Mean Evan's Blue permeation was graphed with Standard deviation, and statistics carried out using one-way analysis of variance with a TukeyKramer post-test for multiple comparisons, with $P \leq 0.05$ representing significance.

\section{Results}

\subsection{Endostatin inhibits $\mathrm{VEGF}_{165}$ mediated permeability in retinal microvascular cells in vitro}

When $\operatorname{VEGF}_{165}\left(10 \mathrm{ng} \mathrm{ml}^{-1}\right)$ was added to a trans-well insert a significant increase in the paracellular permeability of RMEC's as determined by FD-70 (Fig. 1A) and FD-4 (Fig. 1B) flux across the monolayer compared to Control (Un-treated) cells $(P \leq 0.05)$. Simultaneous treatment of cells with $10 \mathrm{ng} \mathrm{ml}^{-1} \mathrm{VEGF}_{165}$ and $20 \mathrm{ng} \mathrm{ml}^{-1}$ Endostatin, however, showed a marked decrease in VEGF $_{165}$ mediated FD-70 flux across the monolayer, as did initial treatment for $2 \mathrm{hr}$ with $10 \mathrm{ng} \mathrm{ml}^{-1} \mathrm{VEGF}_{165}$ followed by treatment with $20 \mathrm{ng} \mathrm{ml}^{-1}$ endostatin $(P \leq 0.05)$ with regards to FD-70 and FD-4 flux across the monolayer (Fig. 1A and B).

Full-size image (62K)

Fig. 1. Treatment of RMEC's with $10 \mathrm{ng} \mathrm{ml}^{-1}$ VEGF for $24 \mathrm{hr}$ elicited a significant increase in the apparent permeability coefficient $\left(P_{\text {app }}\right)$ across the monolayer of RMEC's with respect to FD-70 ( $* * * P=0.0001)$ (Fig. 1A). This VEGF mediated permeability was shown to decrease significantly upon treatment of cells for $24 \mathrm{hr}$ 
with $20 \mathrm{ng} \mathrm{ml}^{-1}$ Endostatin (***P=0.0001). RMEC's pre-treated with $20 \mathrm{ng} \mathrm{ml}^{-1}$ Endostatin for $2 \mathrm{hr}$ prior to treatment with $10 \mathrm{ng} \mathrm{ml}^{-1}$ VEGF for $22 \mathrm{hr}$ and cells pretreated for $2 \mathrm{hr}$ with $10 \mathrm{ng} \mathrm{ml}^{-1}$ VEGF and subsequently treated for $22 \mathrm{hr}$ with $20 \mathrm{ng} \mathrm{ml}^{-1}$ Endostatin also showed significant decreases in permeability compared to $10 \mathrm{ng} \mathrm{ml}^{-1}$ VEGF treatment alone. $(n=3)$. $(* * * P=0.0001) .20 \mathrm{ng} \mathrm{ml}^{-1}$ Endostatin was also shown to significantly decrease the VEGF induced increases in flux of FD-4 across the RMEC monolayer. $10 \mathrm{ng} \mathrm{ml}^{-1} \mathrm{VEGF}_{165}$ pre-treatment for $2 \mathrm{hr}$ followed by $22 \mathrm{hr}$ incubation of cells with $20 \mathrm{ng} \mathrm{ml}^{-1}$ Endostatin elicited a significant decrease in permeability ( $* P=0.0449$ ), whilst pre-treatment with $20 \mathrm{ng} \mathrm{ml}^{-1}$ Endostatin for $2 \mathrm{hr}$ and subsequent treatment for $22 \mathrm{hr}$ with $10 \mathrm{ng} \mathrm{ml}^{-1} \mathrm{VEGF}_{165}$ also decreased VEGF mediated permeability $(* P=0.0229)$. $(n=3)$. (Fig. 1B).

\subsection{Endostatin causes a dose dependent increase in occludin expression}

RMEC's exposed to increasing concentrations of Endostatin $\left(10 \mathrm{ng} \mathrm{ml}^{-1}, 100 \mathrm{ng} \mathrm{ml}^{-1}\right.$, $1 \mu \mathrm{g} \mathrm{ml}^{-1}, 10 \mu \mathrm{g} \mathrm{ml}^{-1}$ ), showed a dose dependent increase in levels of occludin expression, which were shown to be significant after densitometric analysis $(P \leq 0.05)$ (Fig. 2A and B). Control, untreated, RMEC's showed Occludin migrating as a band of molecular weight $62 \mathrm{kDa}$, and a band migrating at approximately $60 \mathrm{kDa}$. However, upon treatment of RMEC's with increasing concentrations of Endostatin, the levels of expression of Occludin were shown to increase 3-fold. Both the $62 \mathrm{kDa}$, and $60 \mathrm{kDa}$ forms of occludin were shown to increase. Western blots were normalised with $\beta$ actin.

Full-size image $(41 \mathrm{~K})$

Fig. 2. Control (untreated) RMEC's showed Occludin migrating as a band of molecular weight $62 \mathrm{kDa}$, and a band migrating at approximately $60 \mathrm{kDa}$ (Fig. 2A). However, upon treatment of RMEC's for $24 \mathrm{hr}$ with increasing concentrations of Endostatin $\left(10 \mathrm{ng} \mathrm{ml}^{-1}, 100 \mathrm{ng} \mathrm{ml}^{-1}, 1 \mu \mathrm{g} \mathrm{ml}^{-1}\right.$ and $\left.10 \mu \mathrm{g} \mathrm{ml}^{-1}\right)$, the levels of expression of Occludin were shown to increase in a dose-dependent manner (100 $\mathrm{ng} \mathrm{ml}^{-1}$ Endostatin $* * * P=0.0002,1 \mu \mathrm{g} \mathrm{ml}^{-1}$ Endostatin $* * * P<0.0001,10 \mu \mathrm{g} \mathrm{ml}^{-1}$ Endostatin $* * * P<0.0001)$.(Fig. 2B). The 62 , and $60 \mathrm{kDa}$ forms of occludin were both shown to increase. Western blots were normalised using $\beta$-actin. $(n=3)$.

\subsection{Endostatin causes increased phosphorylation of occludin on serine and threonine residues}

RMEC's serum deprived and treated for $24 \mathrm{hr}$ with $100 \mathrm{ng} \mathrm{ml}^{-1}$ Endostatin showed increased phosphorylation of Occludin on Serine and Threonine residues, but not 
Tyrosine as determined by immunoprecipitation using phospho-specific antibodies (Fig. 3A). Phosphorylation status of serine residues on occludin was also ascertained by pre-treatment of cell lysates with $50 \mathrm{U} \mathrm{ml}^{-1}$ Alkaline Phosphatase prior to immunoprecipitation with rabbit anti-occludin antibody. Phosphorylated serine residues on occludin (pre-treated with endostatin for $24 \mathrm{hr}$ ) were not detected in alkaline phosphatase-treated samples (Fig. 3B) but were present in samples which had not been subjected to alkaline phosphatase treatment (Fig. 3B).

\section{Full-size image $(48 \mathrm{~K})$}

Fig. 3. RMEC's treated with $100 \mathrm{ng} \mathrm{ml}^{-1}$ Endostatin for $24 \mathrm{hr}$ showed an increase in phosphorylation of occludin on serine and threonine residues compared to the control (un-treated) cells (Fig. 3A). The large molecular weight band at $62 \mathrm{kD}$ representing phosphorylated serine residues on occludin was not present in lanes 3 and 4, corresponding to cell lysates which had been treated for $1 \mathrm{hr}$ with $20 \mathrm{U} \mathrm{ml}^{-1}$ Alkaline Phosphatase prior to immunoprecipitation with anti-occludin antibody (Fig. 3B), providing further evidence of specific phosphorylation of occludin in endostatintreated samples (Fig. 3B).

This provides further evidence for increased phosphorylation of occludin in endostatin-treated RMEC.

\subsection{Levels of expression of ZO-1 remain un-changed upon treatment of RMEC's with VEGF 165 or Endostatin}

RMEC's treated with $100 \mathrm{ng} \mathrm{ml}^{-1} \mathrm{VEGF}_{165}$ or $100 \mathrm{ng} \mathrm{ml}^{-1}$ Endostatin did not elicit any significant change in the levels of expression of the tight junction protein ZO-1 after Western blot analysis. This experiment was repeated three times and statistical analyses of results performed using Student's $t$-test (Fig. 4A and B).

Full-size image $(44 \mathrm{~K})$

Fig. 4. Control (untreated) RMEC's showed the tight junction protein ZO-1 migrating as a doublet at approximately $220 \mathrm{kDa}$. This doublet represents the two isoforms $\mathrm{ZO}$ $1 \alpha^{+}$and ZO- $1 \alpha^{-}$. Upon treatment of cells with $100 \mathrm{ng} \mathrm{ml}^{-1} \mathrm{VEGF}_{165}$ for $24 \mathrm{hr}$, the 
levels of ZO-1 expression did not change significantly.(Fig. 4A and B). Treatment of cells with $100 \mathrm{ng} \mathrm{ml}^{-1}$ Endostatin for $24 \mathrm{hr}$ resulted in no significant change in ZO-1 expression $(n=3)$. Western blot analysis was normalised using $\beta$-actin.

\subsection{Endostatin antagonises VEGF-mediated retinal vascular permeability in C57/B16 mice}

C57/B16 mice administered with an intra-ocular injection of $30 \mathrm{ng} \mathrm{VEGF}_{165}$ showed a significant increase in Evan's blue/albumin permeation at the BRB after $24 \mathrm{hr}$ compared to un-injected mice and mice administered a control injection with no solution. This VEGF mediated increase in Evan's blue/albumin permeation at the BRB was shown to significantly decrease upon administration of a solution containing $30 \mathrm{ng}$ VEGF +60 ng Endostatin. Mean Evan's Blue/albumin permeation was graphed with Standard deviation, and statistics carried out using one-way analysis of variance with a Tukey-Kramer post-test for multiple comparisons, with $P \leq 0.05$ representing significance (Fig. 5).

\section{Full-size image $(35 \mathrm{~K})$}

Fig. 5. Mice injected intra-ocularly through the sclera, in the region of the ciliary body with $30 \mathrm{ng} \mathrm{VEGF}_{165}$, showed a significant increase in Evan's blue/albumin permeation at the BRB after $24 \mathrm{hr}$ compared to un-injected mice and mice administered a control injection with no solution ( $* * P=0.001)$. Whilst $60 \mathrm{ng}$ Endostatin alone elicited no significant change in retinal permeability, $\mathrm{VEGF}_{165}$ mediated increases in Evan's blue/albumin permeation at the BRB was shown to significantly decrease upon administration of a solution containing $30 \mathrm{ng}$ VEGF $+60 \mathrm{ng}$ Endostatin $(* * P=0.001)$. Mean Evan's Blue/albumin permeation was graphed with Standard deviation, and statistics carried out using one-way analysis of variance with a Tukey-Kramer posttest for multiple comparisons, with $P \leq 0.05$ representing significance.

\section{Discussion}

RMECs at early passage in vitro demonstrate a phenotype that suggests aspects of the iBRB are maintained in culture (e.g. tight junction expression, low TEER values) (Tretiach et al., 2003 and Stitt et al., 2000). This makes these cells a reasonable model system to dissect aspects of the iBRB. Indeed, using endothelial monolayers, several groups have demonstrated rapid ( $<30 \mathrm{~min}$ ) VEGF-mediated increases in permeability indicating evocation of several pathways including initiation of transcellular gaps, vesiculovacuolar organelle formation and fenestrations (Bates et al., 1999, Esser et al., $\underline{1998}$ and Feng et al., 1996). Behzadian et al. (2003), have found a rapid and transient 
phase followed by a delayed and sustained phase of VEGF-induced permeability. We were interested in blood retinal barrier breakdown when the tight junction barrier breaks and paracellular permeability begins to increase, and we carried out all growth factor treatments for $24 \mathrm{hr}$. The current investigation shows that treatment with VEGF $_{165}$ for $24 \mathrm{hr}$ increases the permeability between RMEC's with the mechanism likely to be the paracellular route, as permeability changes due to VEGF have previously been shown to be accompanied by changes in expression, phosphorylation and re-distribution of tight junction proteins (Antonetti et al., 1999). We have found that endostatin, whilst increasing levels of expression, also induced occludin phosphorylation on serine and threonine residues. Increased phosphorylation of occludin on specific serine or threonine residues may affect its interactions with ZO1, ZO-2, or ZO-3, which interact with the C-terminal tail of occludin.

We show endostatin reversed the effects of VEGF-enhanced permeability between RMECs. The effects of endostatin on VEGF mediated permeability, and the increase in the levels of expression of occludin by endostatin treatment, may serve to regulate the tight junction at the blood retinal barrier. As a $20 \mathrm{kDa}$ fragment of collagen XVIII, endostatin is a normal component of the basement membranes that surround the vascular tubes and acts as a potent angiogenesis inhibitor in the eye (Mori et al., 2001), possibly acting through a number of cell surface molecules that may serve as endostatin receptors (Dixelius et al., 2002). Endostatin has been shown to affect several endothelial cell functions including migration, survival, proteinase activity and vessel stabilisation (Dixelius et al., 2002). The circulating plasma level of endostatin in normal human control subjects is $10-50 \mathrm{ng} \mathrm{ml}^{-1}$ (Feldman et al., 2002) and in the eye it has been shown that vitreous levels of the peptide are higher than plasma levels in patients with proliferative diabetic retinopathy (Funatsu et al., 2003). Using physiological levels of endostatin in a relevant in vitro system, the current study describes the effects of this peptide on retinal microvascular endothelial cell function. In a model of the $\mathrm{BRB}$, it is evident that this vasoactive peptide can promote integrity of the retinal endothelial barrier.

In the current investigation we examined physiological levels of endostatin and how this would affect tight junction integrity and perhaps account for the observed reversal of VEGF-mediated permeability. Treatment of RMEC's with $1 \mu \mathrm{g} \mathrm{ml}^{-1}$ of endostatin induced a two-fold increase in occludin expression. Endostatin induced posttranslational modifications to occludin as seen with increased serine and threonine phosphorylation (Fig. 3). There are no previous reports of the effects of endostatin on tight junction expression in the literature, although interestingly the endothelial cell adherens junctional protein $\beta$-catenin is tyrosine phosphorylated in response to acute treatment with endostatin (Dixelius et al., 2003).

We show that endostatin increases occludin levels after $24 \mathrm{hr}$ treatment, suggesting that this peptide may regulate capillary permeability through modulation of occludin at the BRB. Indeed, expression levels of occludin have been shown to correlate with barrier properties in different tissues (Harhaj and Antonetti, 2004). Endostatin treatment reversed the VEGF-enhanced permeability, suggesting endostatin may act to maintain BRB permeability in the event of the VEGF-induced vasopermeability. The mechanism may involve upregulation in the levels of expression of the tight junction protein occludin. 
Our results on $\mathrm{BRB}$ integrity in vivo also show how $\mathrm{VEGF}_{165}$ mediated retinal permeability can be decreased with physiological levels of endostatin. No statistically significant differences were found for control, inject-control and endostatin-injected animals for retinal Evans Blue leakage. Animals injected with $\mathrm{VEGF}_{165}$ showed a statistically significant increase in retinal Evans Blue leakage (Xu et al., 2001). When mice were injected with $\mathrm{VEGF}_{165}$ plus endostatin we found a statistically significant decrease in retinal Evans Blue leakage, compared to VEGF-treated mice, showing endostatin can reduce VEGF-mediated increases in vascular permeability. Our data suggest that endostatin could be of therapeutic value in ocular diseases where increased retinal vasopermeability exists. This is the first report of an antagonistic effect of endostatin on VEGF-mediated retinal vascular permeability using a relatively small dose of endostatin (60 ng), and of effects of endostatin on BRB tight junction proteins. The fact that low levels of endostatin can elicit this effect may be important when considering therapeutic delivery approaches.

It is significant that endostatin was shown to reverse VEGF-mediated increases in vasopermeability. Indeed, an in vivo study by Takahashi et al. (2003) showed intraocular expression of endostatin suppressed leakage of intravascular $\left[{ }^{3} \mathrm{H}\right]$ mannitol into the retina. However, it was not possible to determine concentrations of endostatin that have an effect using this experimental approach. Our data indicate that $20 \mathrm{ng} \mathrm{ml}^{-1}$ of endostatin is sufficient to suppress VEGF-mediated increases in permeability across RMEC monolayers in vitro whilst $60 \mathrm{ng}$ Endostatin will decrease VEGFmediated permeability in vivo.

VEGF exerts its effect through binding to its two receptor tyrosine kinases, KDR/Flk1 and Flt-1, expressed on endothelial cells. Endostatin blocks VEGF-induced tyrosine phosphorylation of KDR/Flk-1 and activation of ERK, p38MAPK, and p125 ${ }^{\mathrm{FAK}}$, which are downstream events of KDR/Flk-1 signalling. Several cell surface expressed molecules, including glypican-1 and -4 , may serve as endostatin receptors. Although endostatin has been shown to bind to the extracellular domains of KDR/Flk-1 and Flt1 resulting in receptor activation being blocked (Kim et al., 2002) it has also been shown that endostatin does not affect intracellular signalling cascades implicated in cellular migration and proliferation suggesting endostatin does not directly affect the VEGF receptor.

Data obtained in the current study suggests endostatin may exert its affect on vasopermeability by upregulating occludin levels and phosphorylation of occludin on serine and threonine residues. We are currently determining the specific serine and threonine residues involved, and the resulting conformational changes. As far as we are aware, this is the first report of the effects of endostatin on endothelial tight junction properties and we describe a novel increase in occludin expression and phosphorylation. This novel effect of endostatin in an in vitro model of the inner blood retinal barrier function and it's effect on BRB integrity in vivo decrees that this peptide should be further studied for its potential to prevent clinically significant retinal vasopermeability changes.

\section{Acknowledgements}

We acknowledge Fighting Blindness and the Wellcome Trust for funding this study. 


\section{References}

Antonetti et al., 1999 D.A. Antonetti, A.J. Barber, L.A. Hollinger, E.B. Wolpert and T.W. Gardner, Vascular endothelial growth factor induces rapid phosphorylation of tight junction proteins occludin and zonula occluden 1. A potential mechanism for vascular permeability in diabetic retinopathy and tumors, J. Biol. Chem. 274 (1999), pp. 23463-23467. Full Text via CrossRef | View Record in Scopus | Cited By in $\underline{\text { Scopus }(240)}$

Auricchio et al., 2002 A. Auricchio, K.C. Behling, A.M. Maguire, E.M. O'Connor, J. Bennett, J.M. Wilson and M.J. Tolentino, Inhibition of choroidal neovascularization by intravenous injection of adenoviral vectors expressing secretable endostatin, Am.J. Pathol. 159 (2002), pp. 313-320.

Balda et al., 1996 M.S. Balda, J.M. Anderson and K. Matter, The SH3 domain of the tight junction protein $\mathrm{ZO}-1$ binds to a serine protein kinase that phosphorylates a

region C-terminal to this domain, FEBS Lett. 399 (1996), pp. 326-332. Article | $\underline{\text { PDF (806 K) }}$ | View Record in Scopus $\mid$ Cited By in Scopus (71)

Barber, A.J Barber, A.J., Antonetti, D.A., 2003. Mapping the blood vesseles with paracelluar permeability in the retinas od diabetic rats. Invest, Opthalmol, Vis. Sci, 44(12):5410-5416.

Bates et al., 1999 D.O. Bates, D. Lodwick and B. Williams, Vascular endothelial growth factor and microvascular permeability, Microcirculation 6 (1999), pp. 83-96 Review. Full Text via CrossRef | View Record in Scopus | Cited By in Scopus (81)

Behzadian et al., 2003 M.A. Behzadian, L.J. Windsor, N. Ghaly, G. Liou, N.T. Tsai and R.B. Caldwell, VEGF-induced paracellular permeability in cultured endothelial cells involves urokinase and its receptor, FASEB J. 17 (2003), pp. 752-754. View

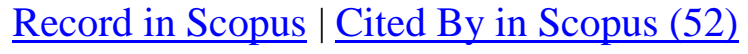

Carney et al., 1986 M.D. Carney, R.R. Paylor, J.G. Cunha-Vaz, L.M. Janpol and M.E. Goldberg, Iatrogenic choroidal neovascularisation in sickle cell retinopathy, Ophthalmology 93 (1986), pp. 1163-1168. View Record in Scopus | Cited By in $\underline{\text { Scopus (8) }}$

Dixelius et al., 2002 J. Dixelius, M. Cross, T. Matsumoto, T. Sasaki, R. Timpl and L. Claesson-Welsh, Endostatin regulates endothelial cell adhesion and cytoskeletal organization, Cancer Res. 62 (2002), pp. 1944-1947. View Record in Scopus | Cited By in Scopus (91)

Dixelius et al., 2003 J. Dixelius, M. Cross, T. Matsumoto and L. Claesson-Welsh, Endostatin action and intracellular signalling: $\beta$-catenin as a potential target?, Cancer

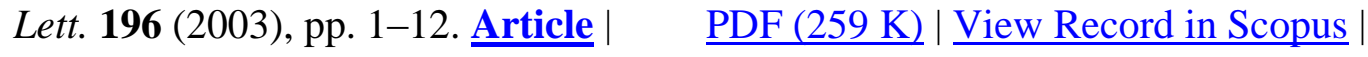
Cited By in Scopus (33) 
Dorchy, 1993 H. Dorchy, Characterisation of early stages of diabetic retinopathy, Diabetes Care 16 (1993), pp. 1212-1214. View Record in Scopus |Cited By in $\underline{\text { Scopus }(9)}$

Dye et al., 2001 J.F. Dye, L. Leach, P. Clark, J.A. Firth and A.M.P. Cyclic, and acidic fibroblast growth factor have opposing effects on tight and adherens junctions in microvascular endothelial cells in vitro, Microvasc. Res. 62 (2001), pp. 94-113.

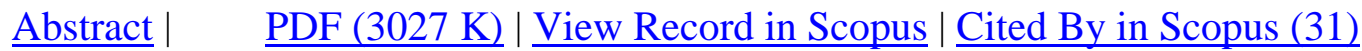

Esser et al., 1998 S. Esser, K. Wolburg, H. Wolburg, G. Breier, T. Kurzchalia and W. Risau, Vascular endothelial growth factor induces endothelial fenestrations in vitro, $J$. Cell Biol. 140 (1998), pp. 947-959. Full Text via CrossRef | View Record in Scopus | Cited By in Scopus (345)

Feldman et al., 2002 A.L. Feldman, H.R. Alexander Jr, J.C. Yang, W.M. Linehan, R.A. Eyler, M.S. Miller, S.M. Steinberg and S.K. Libutti, Prospective analysis of circulating endostatin levels in patients with renal cell carcinoma, Cancer 95 (2002), pp. 1637-1643. Full Text via CrossRef | View Record in Scopus | Cited By in Scopus $\underline{(45)}$

Feng et al., 1996 D. Feng, J.A. Nagy, J. Hipp, H.F. Dvorak and A.M. Dvorak, Vesiculo-vacuolar organelles and the regulation of venule permeability to macromolecules by vascular permeability factor, histamine, and serotonin, J. Exp. Med. 183 (1996), pp. 1981-1986. Full Text via CrossRef | View Record in Scopus | Cited By in Scopus (168)

Funatsu et al., 2003 H. Funatsu, H. Yamashita, H. Noma, H. Mochizaki, T. Mimura, T. Ikeda and S. Hori, Outcome of vitreous surgery and the balance between vascular endothelial growth factor and endostatin, Invest. Ophthalmol. Vis. Sci. 44 (2003), pp. 1042-1047. Full Text via CrossRef | View Record in Scopus | Cited By in Scopus $\underline{(35)}$

Gonzalez-Mariscal et al., 2003 L. Gonzalez-Mariscal, A. Betanzos, P. Nava and B.E. Jaramillo, Tight junction proteins, Prog. Biophys. Mol. Biol. 81 (2003), pp. 1-44.

$\underline{\text { Article }}|\underline{\text { PDF }(1518 \mathrm{~K})}| \underline{\text { View Record in Scopus }} \mid \underline{\text { Cited By in Scopus (386) }}$

Halfter et al., 1998 W. Halfter, S. Dong, B. Schurer and G.J. Cole, Collagen XVIII is a basement membrane heparan sulfate proteoglycan, J. Biol. Chem. 273 (1998), pp. 25404-25412. Full Text via CrossRef | View Record in Scopus | Cited By in Scopus $\underline{(196)}$

Harhaj and Antonetti, 2004 N.S. Harhaj and D.A. Antonetti, Regulation of tight junctions and loss of barrier function in pathophysiology, Int. J. Biochem. Cell Biol.

3697 (2004), pp. 1206-1237. Article | PDF (431 K) | View Record in Scopus |

Cited By in Scopus (153) 
Kim et al., 2002 Y.M. Kim, S. Hwang, Y.M. Kim, B.J. Pyun, T.Y. Kim, S.T. Lee, Y.S. Gho and Y.G. Kwon, Endostatin blocks vascular endothelial growth factormediated signaling via direct interaction with KDR/Flk-1, J. Biol. Chem. 277 (2002), pp. 27872-27879. Full Text via CrossRef | View Record in Scopus | Cited By in $\underline{\text { Scopus (197) }}$

Kurihara et al., 1995 H. Kurihara, J.M. Anderson and M.G. Farquhar, Increased Tyr phosphorylation of ZO-1 during modification of tight junctions between glomerular foot processes, Am. J. Physiol. 268 (1995), pp. 514-524.

Le Gat et al., 2003 L. Le Gat, K. Gogat, C. Bouquet, M. Saint-Geniez, D. Darland, L. Van Den Berghe, D. Marchant, A. Provost, M. Perricaudet, M. Menasche and M. Abitbol, In vivo adenovirus-mediate delivery of a uPA/uPAR antagonist reduces retinal neovascularisation in a mouse model of retinopathy, Gene Ther. 10 (2003), pp. 2098-2103. Full Text via CrossRef $\mid$ View Record in Scopus $\mid$ Cited By in Scopus (17)

Maik-Rachline et al., 2004 G. Maik-Rachline, S. Shaltiel and R. Seger, Extracellular phosphorylation converts pigment epithelium-derived factor from a neurotrophic to an antiangiogenic factor, Blood (2004).

Mori et al., 2001 K. Mori, A. Ando, P. Gehlbach, D. Nesbitt, K. Takahashi, D. Goldsteen, M. Penn, C.T. Chen, K. Mori, M. Melia, S. Phipps, P. Moffat, K. Brazzell, D. Liau, K.H. Dixon and P.A. Campochiaro, Inhibition of choroidal neovascularization by intravenous injection of adenoviral vectors expressing secretable endostatin, Am. J. Pathol. 159 (2001), pp. 313-320. Abstract | Article |

\section{$\underline{\text { PDF (1234 K) } \mid \text { View Record in Scopus } \mid \text { Cited By in Scopus (96) }}$}

O'Reilly et al., 1997 M.S. O'Reilly, T. Boehm, Y. Shing, N. Fukai, G. Vasios, W.S. Lane, E. Flynn, J.R. Birkhead, B.R. Olsen and J. Folkman, Endostatin: an endogenous inhibitor of angiogenesis and tumor growth, Cell 88 (1997), pp. 277-285. Article |

\section{$\underline{\text { PDF (2873 K) }}|\underline{\text { View Record in Scopus }}| \underline{\text { Cited By in Scopus (2838) }}$}

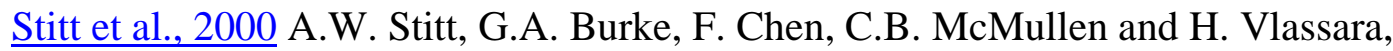
Advanced glycation end-product receptor interactions on microvascular cells occur within caveolin-rich membrane domains, FASEB J. 14 (2000), pp. 2390-2392. View

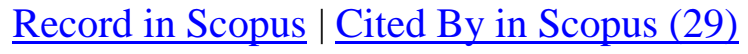

Takahashi et al., 2003 K. Takahashi, Y. Saishin, Y. Saishin, R. Lima Silva, Y. Oshima, S. Oshima, M. Melia, B. Paszkiet, D. Zerby, M. Kadan, G. Liau, M. Kaleko, S. Connelly, T. Luo and P.A. Campochiaro, Intraocular expression of endostatin reduces VEGF-induced retinal vascular permeability, neovascularisation, and retinal detachment, FASEB J. 17 (2003), pp. 896-898. View Record in Scopus | Cited By in $\underline{\text { Scopus (72) }}$ 
Takata et al., 1997 K. Takata, H. Hirano and M. Kasahara, Transport of glucose across the blood-tissue barriers, Int. Rev. Cytol. 172 (1997), pp. 1-53 Review.

$\underline{\text { Abstract }}|\underline{\text { PDF }(3507 \mathrm{~K})}| \underline{\text { View Record in Scopus }} \mid \underline{\text { Cited By in Scopus (60) }}$

Toker and Cantley, 1997 A. Toker and L.C. Cantley, Signalling through the lipid products of phosphoinositide-3-OH kinase, Nature 387 (1997), pp. 673-676 Review. $\underline{\text { Full Text via CrossRef } \mid \text { View Record in Scopus | Cited By in Scopus (969) }}$

Tretiach et al., 2003 M. Tretiach, D. van Driel and M.C. Gillies, Transendothelial electrical resistance of bovine capillary endothelial cells is influenced by cell growth patterns: an ultrastructural study, Clin. Exp. Ophthalmol. 31 (2003), pp. 348-353. Full

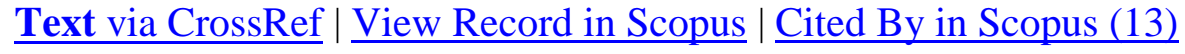

Vinores et al., 1995 S.A. Vinores, M. Kuchlem, N.L. Derevjank, J.D. Henderer, J. Mahlow, W.R. Green and P.A. Campochiaro, Blood-retinal barrier breakdown in retinitis pigmentosa: light and electron microscopic immunolocalisation, Histol. Histopathol. 10 (1995), pp. 913-923. View Record in Scopus | Cited By in Scopus $\underline{(29)}$

Vinores et al., 1999 S.A. Vinores, N.L. Derevjank, H. Ozaki, N. Okamoto and P.A. Campochiaro, Cellular mechanisms of blood-retinal barrier dysfunction in macular edema, Doc. Ophthalmol. 97 (1999), pp. 217-228. Full Text via CrossRef $\mid$ View $\underline{\text { Record in Scopus } \mid \text { Cited By in Scopus (30) }}$

Wong, 1997 Wong, Phosphorylation of occludin correlates with occludin localization and function at the tight junction, Am. J. Physiol. 273 (1997), pp. 1859-1867.

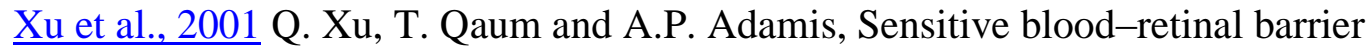
breakdown quantitation using Evans blue, Invest. Ophthalmol. Vis. Sci. 42 (2001), pp. 789-794. View Record in Scopus | Cited By in Scopus (92) 